\title{
The Bid-Ask Spread in the Danish Stock Market: Evidence from the $1990 \mathrm{~s}$
}

\author{
Torben Voetmann ${ }^{1}$ \\ ${ }^{1}$ University of San Francisco, The Brattle Group, San Francisco, USA \\ Correspondence: Torben Voetmann, University of San Francisco and The Brattle Group, San Francisco, CA \\ 94105, USA. Tel: 1-415-217-1000. E-mail: torben.voetmann@brattle.com
}

Received: July 2, 2016

doi:10.5539/ijef.v8n9p127
Accepted: July 22, 2016

Online Published: August 25, 2016

\begin{abstract}
This paper investigates the cost components of bid-ask spreads around earnings announcements on the small Danish stock market in the 1990s. The results indicate that negative earnings surprises convey pricing information, suggesting the existence of significant information asymmetry between market makers and informed traders. Negative earnings surprises resulted in an increase in adverse-selection cost and trading volume while inventory-holding and order-processing costs decreased, leading to a combined decrease in the realized spread. The change in the realized spread is significant, while the change in the quoted bid-ask spread is negligible. Overall, the results suggest that informed traders' ability to assess firms' performance in the Danish stock market affects the bid-ask spread around announcements of earnings. The observed changes in cost components on the small Danish stock market are similar to those observed in larger and more active capital markets.
\end{abstract}

Keywords: bid-ask spread, earnings surprises, asymmetric information, order-processing costs, inventory costs

\section{Introduction}

This paper investigates the cost components of the bid-ask spread and analyzes the changes in the spread around announcements of earnings by companies listed on the Copenhagen Stock Exchange (CSE). The Danish stock market is one of the smaller and less active capital markets in Europe with less than approximately 200 companies actively trading and a total market capitalization of $€ 160$ billion. In larger and more active capital markets, it has been shown that stock prices typically respond to earnings announcements and that their response can be partitioned into positive or negative earnings surprises. It has further been established that earnings announcements convey pricing information, providing a cost advantage to informed investors. Several studies also explain the impact that the quoted bid-ask spread has on asset returns. (Note 1) Studies of the quoted and realized bid-ask spread examine three cost components: adverse-selection, inventory-holding, and order-processing. (Note 2) These three components of the quoted bid-ask spread explain the market makers' expected compensation for making transactions. However, the market makers' realized compensation for providing liquidity service is the effective bid-ask spread. Stoll (1989) found that the quoted spread is almost always less than the realized spread and in the United State it is approximately half the quoted spread. To compare against existing studies on larger capital markets, this paper examines the economic magnitude and information content of the effective bid-ask spreads based on earnings announcements by companies on listed on the CSE.

This paper builds on prior related analysis of larger, more heavily traded markets. Studying markets of smaller sizes is useful for improving the understanding gleaned from the results of older studies of larger markets. For example, while examining earnings announcements in an active capital market, Krinsky and Lee (1996) predict an increase in adverse-selection costs immediately prior to earnings announcements because market makers possibly face a greater probability of trading with an informed trader who may possess superior information about expected earnings. They also predict that adverse-selection costs stay elevated immediately after earnings announcements because informed traders can better assess a firm's performance on the basis of the announcements. Using information asymmetric models, early research of the adverse-selection cost suggests that greater information asymmetry between traders and market makers induces a wider bid-ask bounce. Because market participants incorporate superior information about expected earnings into the pricing process, market 
makers are forced to widen this component of the spread as a temporary protection against information asymmetry.

This study confirms that in the Danish stock market, the absolute size of the bid-ask spread does not change around earnings announcements, but there are significant changes among the individual components of the spread, including an increase in the adverse-selection cost (from 52 percent of the spread immediately before the earnings announcements to 72 percent around the earnings announcements). The economic magnitude of these cost components is similar to those observed in larger capital markets (Gregoriou, 2013). Krinsky and Lee (1996) hypothesize that the increase in adverse-selection costs indicates an increase in market makers' informational uncertainty about informed traders. This study demonstrates that on the Danish stock market this predicted increase in adverse selection cost is offset by a decrease in inventory-holding and order-processing costs, with the result that the bid-ask spread is unchanged around earnings announcements.

This result is particularly pronounced around negative earnings surprises as compared to positive earnings surprises. A potential explanation for this result is that companies announcing lower than expected earnings create greater uncertainty among market participants than positive news. Overall, the results of studying the bid-ask spread of securities listed on the Danish stock market show evidence of a state of temporarily increased information asymmetry. This empirical observation is consistent with evidence from studying similar and larger capital markets (Note 3).

\section{Explanations of the Bid-Ask Spread}

Ho and Stoll $(1981,1983)$ made the first direct attempt to model the cost components of the bid-ask spread, further refining our understanding from earlier studies by Demsetz (1968) and Tinic (1972), which describe the market makers' ability to provide market participants liquidity service. Ho and Stoll $(1981,1983)$ explain the behavior of market makers as a necessary feature of trading activity occurring under conditions of uncertainty, noting that the bid-ask spread compensates market makers for changing their positions away from their preferred inventory levels. This inventory-holding cost is the part of the bid-ask spread that reflects the return to market makers for accumulating undesired inventory, i.e., the value of risks undertaken by specialists when they sustain a portfolio of stocks that is not fully diversified. The market makers uses the quoted bid-ask spread to adjust inventory holdings by raising (lowing) the bid and ask prices when inventory becomes low (high). Another component of the spread is the order-processing costs, which represents the market makers' costs of providing liquidity and processing services for buy and sell orders. The order-processing cost represents the market makers' fee for matching buying and selling orders and their insurance against failed transactions. Copeland and Galai (1983) and Glosten and Milgrom (1985) demonstrate that market makers' compensation for the risk of completing transactions with traders who possess superior information is obtained through the adverse-selection component. This cost induces a positive bid-ask spread whenever the risk of trading with informed traders is high. (Note 4)

\subsection{Existing Models to Measure the Bid-Ask Spread}

Roll (1984) presents a simple model to account for the impact the bid-ask spread has on asset returns. Roll shows that the covariance of transaction returns represents an estimation of the effective spread, i.e., the realized spread in an efficient market in which the observed market prices depend on a security's fundamental value and the difference between bid and ask prices (see also Stoll, 1989). The transaction price $P_{t}$ is equal to a fixed fundamental value $P_{t}^{v}$ plus half the spread $1 / 2 \cdot S \cdot I_{t}$, where $I_{t}$ is -1 for bid prices and +1 for ask prices. Roll (1984) assumes that $I_{t}$ occurs with equal probabilities whether or not a trade is initiated by a buyer or a seller. Using this simple Roll model, the effective spread is best described by $2 \cdot \sqrt{-\operatorname{cov}}$. A potential weakness in Roll's description of the spread is that it only includes the order-processing cost when considering the fundamental value of the security. In addition, it assumes that the expected return is constant through time and that adverse-selection cost does not exist. Thus, decomposing the bid-ask spread into several components makes it difficult to explain the behavior of the spread while maintaining an assumption of constant expected returns.

Glosten (1985) provides an asymmetric information model to explain the adverse selection cost. Glosten shows that under risk-neutrality the common-information price is given by $P=E\left[P^{v} \mid \Omega\right]$ where $\Omega$ is the publicly available information set and the adverse-selection $\left(A_{a}+A_{b}\right)$, inventory-holding and order-processing $\left(C_{a}+C_{b}\right)$ components are decomposed in the bid and the ask price. The spread is the sum of $A_{a}+A_{b}+C_{a}+C_{b}$. Assuming that all traders have the same information set, Glosten uses the following expectation operator for possible bid and 
ask prices; $a(x)=E\left[P_{v} \mid \Omega \cup\{\right.$ investor buys at $\left.x\}\right]$ and $b(y)=E\left[P_{v} \mid \Omega \cup\{\right.$ investor buys at $\left.y\}\right]$, respectively. Assuming that the market makers determine bid and ask prices such that the expected costs are covered in the spread, the quoted bid and ask prices are:

$$
\begin{aligned}
& P_{a}=a\left(P_{a}\right)+C_{a}=P+\left(a\left(P_{a}\right)-P\right)+C_{a}=P+A_{a}+C_{a} \\
& P_{b}=a\left(P_{b}\right)+C_{b}=P+\left(P-b\left(P_{b}\right)\right)+C_{b}=P+A_{b}+C_{b}
\end{aligned}
$$

An implication of the expected bid and ask prices is that only a portion of the total spread covers the costs. In addition, the impact of the quoted bid-ask spread on the transaction prices is a high correlation between the common information price after the $n$th transaction $\left(P_{n}\right)$ and whether a trade $\left(Q_{n}\right)$ is initiated by the buyer or seller, which takes the value -1 and +1 , respectively. The next transaction price is $E\left[P_{n}\right]=P_{n}+Q_{n}$. Glosten (1985) shows that $P_{n}$ and $Q_{n}$ must be correlated due to the existence of adverse-selection costs. Similar to Roll (1984), Glosten shows that the changes in the transaction prices exhibits temporary reversals that may be attributed to temporarily depressed inventory-holding and order-processing costs while increases to the adverse-selection cost component tend to be permanent. Therefore, it is only the inventory-holding and order-processing costs that cause negative serial correlation in returns, which leads Glosten to argue that Roll's measure of the spread understates the realized spread.

George, Kaul and Nimalendran (1991) provide a model that allows for time-varying returns resulting in unbiased estimates of the spread and its components. They argue that positive autocorrelation in the expected time-varying returns otherwise creates an estimation bias. Stoll (1989) argues for unbiased estimates of the probability of a price reversal and price continuation, however, it has been suggested that Stoll's parameters may also be biased because they depend on nonlinear transformations of prices (e.g., Affleck-Graves, Hedge and Miller, 1994). To eliminate this estimation bias, George et al. (1991) suggest an alternative model that provides unbiased estimators. Their model assumes zero inventory-holding cost and uses OLS-regression to estimate the adverse-selection and order-processing costs of the spread. This model also depends on the assumption that the spread is independent of trade size and that there exists equal ex-ante probabilities for trading at the bid and the ask price. This estimation model allows for variance in the "true" expected return of a security, which affects the estimators of the level of the spread and its components. Affleck-Graves, et al. (1994) propose to test for differences between the cost components of stocks on the New York Stock Exchange (NYSE) and the National Association of Security Dealers Automated Quotations (NASDAQ)/National Market System (NMS). This approach permitted them to separate out the impact on the spread.

$$
S_{i}=\alpha_{0}+\alpha_{1} \cdot S_{q i}+\alpha_{2} \cdot D+\alpha_{3} \cdot\left(D \cdot S_{q i}\right)+\varepsilon
$$

where $S_{i} \equiv 2 \cdot \sqrt{-\operatorname{cov}\left(R D_{i t}, R D_{i t-1}\right)} ; R D_{i t} \equiv R_{i T t}-R_{i B t}, R_{i T t}$ is the continuously compounded transaction return on security $i$ in period $t$ and $R_{i B t}$ is the continuously compounded return from bid quotes following transaction prices; $S_{q i}$ is the quoted spread on security $i$; D is +1 if the stock is quoted on the NASDAQ and 0 if listed on NYSE. The most commonly used methodology to investigate the bid-ask spread follows that proposed by Glosten and Harris (1988), Stoll (1989), and George et al. (1991). However, recent studies are refining the decomposition of the bid-ask spread to examine the observed patterns of spread revisions either through transformations based on the transaction size or serially dependence of the expected returns.

\subsection{The Impact of the Transaction Process on the Bid-Ask Spread}

Roll (1984) argues that the transaction process of asset pricing introduces negative serial dependence. His argument is that observed price changes are not independent because transactions happen at either bid or ask prices causing an anticipated negative serial dependence. Consider the development in the bid-ask spread $S$ at time $t_{0}$, where the ask and bid prices are $P_{o}^{a}$ and $P_{o}^{b}$, respectively, and that all transactions have the same spread, $S$. The transaction price obtained by the market maker arrives randomly within the quoted bid-ask spread and any price within the bid-ask spread is equally likely. This suggests the quoted spread may be different from the effective or realized bid-ask spread. Thus, price changes are dependent on the arrival of unanticipated information arriving to the marketplace, i.e., with no new information there will be no serial covariance in price changes $\left(\Delta P_{t}=P_{t}-P_{t-1}\right)$. If $P^{v}$ is fixed and the quoted prices can only take two values, then the changes in the 
fundamental value $\left(P_{t}^{v}\right)$ displays only volatility and negative serial correlation. If the current transaction price is the ask price $P_{a}$ (the bid price, $\left.P_{b}\right)$ then a price change between $P_{t}$ and $P_{t-1}$ is 0 or s $(0$ or $+\mathrm{s})$. The next price change between $P_{t+1}$ and $P_{t}$ is 0 or $-\mathrm{s}(0$ or s). Thus, the probability distribution for successive price changes that is conditioned on no new information, is dependent on whether the last transaction was at the bid or the ask price. Roll (1984) shows that the variance of the observed prices is dominated by new information while the covariance does not depend on new information assuming efficient markets. Moreover, the spread-induced serial covariance is independent of the time increments in successive prices. Therefore, following Roll's assumption of a constant spread, the bid and ask prices will always bounce symmetrically around the fundamental price because the spread reflects only order-processing costs. This led Stoll (1989) to modify the possible paths of observed market prices with adjustments for inventory-holding costs and adverse-selection costs.

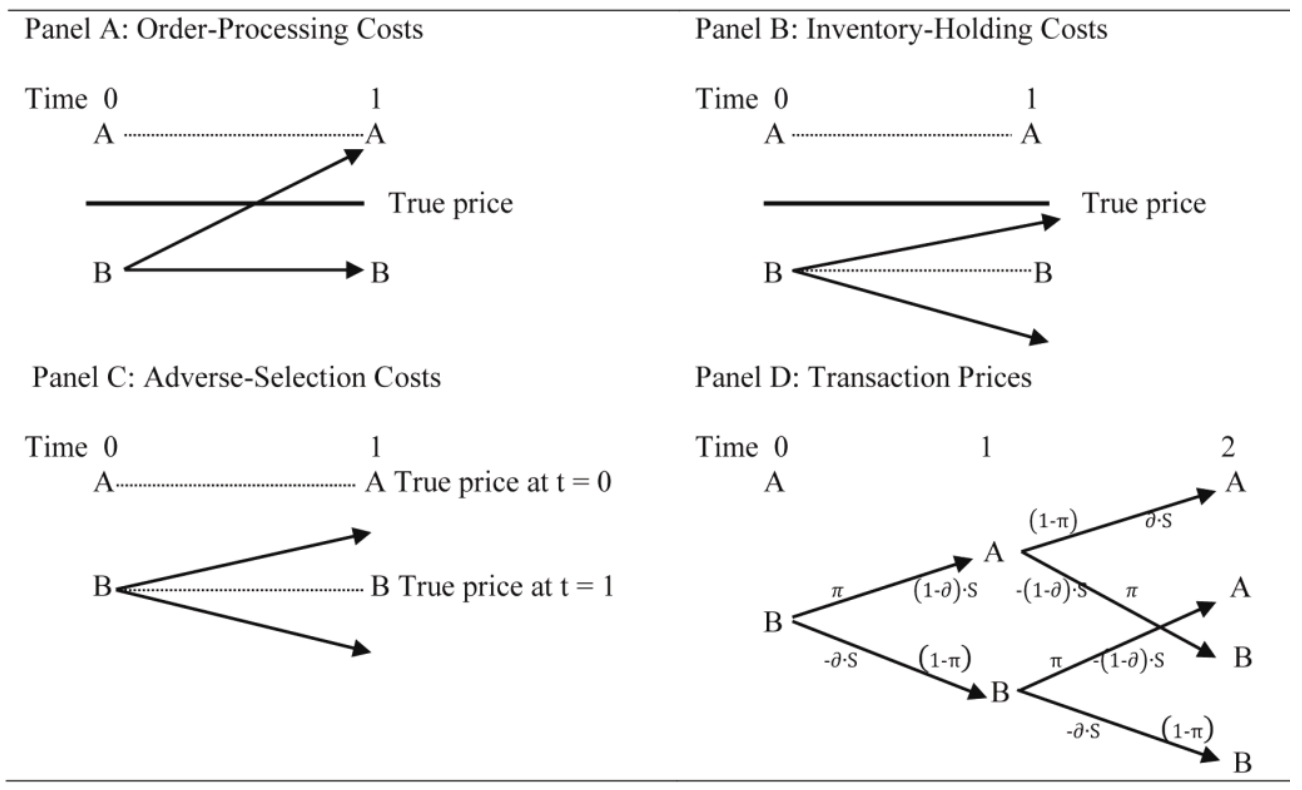

Figure 1. Descriptions of bid-ask spread components

Figure 1, Panel A is similar to Roll's (1984) description of the bid-ask spread that follows a naïve order-processing costs model. Panel B shows the inventory-holding costs as reflected by the spread. Based on these models, the market makers tend to change the spread relative to the fundamental price so that their inventories are maintained around a preferred level. Stoll (1989) argues that new transaction prices are determined in such a way that market makers are indifferent between bid or ask transactions and the inventory-holding costs move symmetrically around the initiated trade price. This leaves the market maker with $0.5 \cdot S$, if a trade is reversed. Panel $\mathrm{C}$ reflects the spread from the adverse-selection costs, which moves similarly to the inventory-holding costs. This is because the transaction at bid (ask) indicates that the expected equilibrium price is assessed by the trader as lower (higher) than the current bid/ask. The price change assumes that traders possess superior information. The expected spread, $\left(P_{o}^{a}-P_{o}^{b}\right) / 2$, changes when a transaction conveys information to the market makers, who revise the expected equilibrium price to $\left(P_{1}^{a}-P_{1}^{b}\right) / 2$. Thus, Roll (1984) identified the differential quoted versus realized spreads, which is different from the opposite effect observed around earnings announcements.

Stoll (1989) extended Roll's (1984) model of the bid-ask spread by estimating the probabilities of price reversal and the magnitude of the price changes. Stoll suggests that the realized spread is smaller than the market makers' quoted spread because it depends only on adverse-selection and inventory-holding costs. Panel D shows all possible sequences of transaction prices starting at the bid price. The price continuation is $\partial: S$ and the size of the price reversal is $(1-\partial) \cdot S$, where $\partial$ is between zero and one. The probability of a price reversal is $\pi$ and a continuation is $(1-\pi)$ and the covariance of transaction prices and quoted prices are: 


$$
\begin{gathered}
\operatorname{Cov}_{\mathrm{p}} \equiv \operatorname{cov}\left(\Delta P_{t}^{p}, \Delta P_{t+1}^{p}\right)=\mathrm{S}^{2}\left[\partial^{2} \cdot(1-2 \pi)-\pi^{2} \cdot(1-2 \partial)\right] \\
\operatorname{Cov}_{\mathrm{a}, \mathrm{b}} \equiv \operatorname{cov}\left(\Delta P_{t}^{a, b}, \Delta P_{t+1}^{a, b}\right)=\mathrm{S}^{2} \cdot \partial^{2} \cdot(1-2 \pi)
\end{gathered}
$$

With a constant spread the serial covariance for bid prices is equal to the serial covariance for ask prices. (Note 5) Empirical evidence shows that the probability of a reversal is greater than 0.5 and that the size of the price reversal $\partial$ less than or equal to 0.5 . As such, Roll (1984) assumes that $\partial$ is equal to 0.0 and $\pi$ is equal to 0.5 in the order processing model while Copeland and Galai (1983) and Glosten and Milgrom (1985) use $\partial$ equal to 0.5 and $\pi$ greater than 0.5 in their adverse-selection model. In the pure inventory-holding model by Ho and Stoll (1985), the parameters are $\partial=0.5$ and $1>\pi>0$.

As discussed above, according to both Roll (1984) and Stoll (1989), the realized spread will be smaller than the quoted spread in the absence of new information. However, in the presences of new information, as explained by Stoll, the three cost components behave differently. The next section discusses the data and estimation of the quoted and realized spread to examine the impact on the spread when new information is learned through announcements of earnings on the Danish stock market.

\section{Data and Empirical Estimation}

\subsection{Data from the Danish Stock Market}

The Danish stock market data includes transaction prices, price quotations, and annual earnings announcements for companies listed on the Copenhagen Stock Exchange between 1989 and 1996. A total of 976 earnings announcements are identified with available data from Datastream. The transaction prices are measured by the daily closing prices and the quoted prices are measured by the bid and ask prices. Observations where the daily bid-ask quotes could not be matched against the closing transaction price were excluded from the analysis. Due to data availability, three broad windows are used to measure the change in the bid-ask spread around the announcements of earnings. The pre-event window is from 45 days to 16 days before an earnings announcement, the event window is from 15 days before to 15 days after an announcement, and the post-event window is 16 days to 45 days following an announcement.

Table 1 shows data characteristics for each type of event window. $\operatorname{Cov}_{b}, \operatorname{Cov}_{a}$, and $\operatorname{Cov}_{p}$ are the serial covariance of daily closing bid, ask and transaction prices. $S$ is the average proportional bid-ask spread. Price is the cross-sectional average stock price in the event window. Volume is the average daily volume of trading in the event window. The turnover variable is the average cross-sectional turnover ratio in each event window. Market value is the average market capitalization in DKK of the companies included in the analysis.

\begin{tabular}{|c|c|c|c|c|c|c|c|c|c|}
\hline $\begin{array}{l}\text { Panel A } \\
\text { Sample size }\end{array}$ & $\begin{array}{r}\text { Pre-F } \\
\mathrm{N}=\end{array}$ & & $\begin{array}{r}\text { Event } \\
\mathrm{N}\end{array}$ & & $\begin{array}{r}\text { Post- } \\
\mathrm{N}=\end{array}$ & & Differer & & \\
\hline $\begin{array}{l}\text { Panel B } \\
\text { Variable } \\
\end{array}$ & Mean & Std & Mean & Std & Mean & Std & $\begin{array}{c}\text { Event - } \\
\text { Pre-Event }\end{array}$ & $\begin{array}{l}\text { Post - } \\
\text { Event }\end{array}$ & $\begin{array}{c}\text { Post - } \\
\text { Pre-Event }\end{array}$ \\
\hline $\operatorname{Cov}_{\mathrm{p}}$ & -0.2604 & 6.0997 & -0.2267 & 4.5169 & -0.5493 & 3.9977 & $\begin{array}{r}0.0337 \\
(0.11)\end{array}$ & $\begin{array}{l}-0.3226 \\
(-1.31)\end{array}$ & $\begin{array}{l}-0.2888 \\
(-0.97)\end{array}$ \\
\hline $\operatorname{Cov}_{\mathrm{a}}$ & -0.3582 & 2.2584 & -1.0416 & 5.4918 & -1.3333 & 4.4319 & $\begin{array}{l}-0.6833 \\
(-2.84)^{\mathrm{a}}\end{array}$ & $\begin{array}{l}-0.2918 \\
(-1.01)\end{array}$ & $\begin{array}{l}-0.9751 \\
(-4.84)^{\mathrm{a}}\end{array}$ \\
\hline $\operatorname{Cov}_{\mathrm{b}}$ & -0.5162 & 4.4649 & -0.8699 & 4.0187 & -1.1401 & 5.9932 & $\begin{array}{c}-0.3536 \\
(-1.45)\end{array}$ & $\begin{array}{l}-0.2703 \\
(-0.91)\end{array}$ & $\begin{array}{l}-0.6239 \\
(-2.05)^{\mathrm{a}}\end{array}$ \\
\hline Spread, \% & 1.72 & 1.44 & 1.72 & 1.34 & 2.18 & 1.56 & $\begin{array}{c}0.00 \\
(0.04)\end{array}$ & $\begin{array}{c}0.46 \\
(3.31)^{\mathrm{a}}\end{array}$ & $\begin{array}{c}0.46 \\
(3.31)^{\mathrm{a}}\end{array}$ \\
\hline Price & 496.18 & 562.46 & 494.27 & 582.60 & 486.12 & 552.24 & $\begin{array}{c}-1.92 \\
(-0.06)\end{array}$ & $\begin{array}{c}-8.15 \\
(-0.26)\end{array}$ & $\begin{array}{l}-10.07 \\
(0.33)\end{array}$ \\
\hline Volume & 16.18 & 36.48 & 19.62 & 50.01 & 15.74 & 35.17 & $\begin{array}{c}3.44 \\
(-1.25)\end{array}$ & $\begin{array}{l}-3.88 \\
(-1.34)\end{array}$ & $\begin{array}{c}-0.44 \\
(-0.12)\end{array}$ \\
\hline $\begin{array}{l}\text { Turnover } \\
\text { Ratio \% }\end{array}$ & 5.20 & 11.47 & 6.06 & 13.43 & 5.18 & 11.11 & $\begin{array}{c}0.87 \\
(1.10)\end{array}$ & $\begin{array}{c}-0.88 \\
(-1.07)\end{array}$ & $\begin{array}{l}-0.01 \\
(-0.05)\end{array}$ \\
\hline Market value & 2121.9 & 3980.1 & 2123.9 & 4128.2 & 2161.4 & 4075.1 & $\begin{array}{c}1.99 \\
(0.01) \\
\end{array}$ & $\begin{array}{l}37.46 \\
(0.29) \\
\end{array}$ & $\begin{array}{l}39.44 \\
(0.31) \\
\end{array}$ \\
\hline
\end{tabular}

Table 1. Descriptive statistics 


\begin{tabular}{|c|c|c|c|c|c|c|c|c|c|}
\hline \multicolumn{10}{|l|}{ Panel C } \\
\hline $\begin{array}{l}\text { Spread, \% } \\
\text { Positive }\end{array}$ & 1.55 & 1.17 & 1.61 & 1.11 & 2.10 & 1.49 & $\begin{array}{c}0.06 \\
(0.59)\end{array}$ & $\begin{array}{c}0.49 \\
(4.34)^{\mathrm{a}}\end{array}$ & $\begin{array}{c}0.55 \\
(4.77)^{\mathrm{a}}\end{array}$ \\
\hline $\begin{array}{l}\text { Spread, \% } \\
\text { Negative }\end{array}$ & 1.96 & 1.63 & 1.91 & 1.54 & 2.30 & 1.65 & $\begin{array}{c}-0.05 \\
(-0.39)\end{array}$ & $\begin{array}{c}0.38 \\
(2.83)^{\mathrm{a}}\end{array}$ & $\begin{array}{c}0.33 \\
(2.39)^{\mathrm{a}}\end{array}$ \\
\hline $\begin{array}{l}\text { Price - } \\
\text { Positive }\end{array}$ & 528.23 & 614.56 & 538.46 & 675.47 & 506.52 & 597,35 & $\begin{array}{l}10.01 \\
(0.18)\end{array}$ & $\begin{array}{l}-31.72 \\
(-0.58)\end{array}$ & $\begin{array}{l}-21.71 \\
(-0.42)\end{array}$ \\
\hline $\begin{array}{l}\text { Price - } \\
\text { Negative }\end{array}$ & 453,23 & 505,39 & 452,46 & 494,08 & 459,77 & 508,48 & $\begin{array}{c}-0,77 \\
(-0.02)\end{array}$ & $\begin{array}{c}7.31 \\
(0.17)\end{array}$ & $\begin{array}{c}6.54 \\
(0.15)\end{array}$ \\
\hline
\end{tabular}

Note. The sample includes 976 earnings announcements from firms on the Copenhagen Stock Exchange between 1989 and 1996. The pre-event window is from 45 days to 16 day before an earnings announcement. The event window is from 15 days before to 15 days after an announcement. The post-event is 16 to 45 days after earnings announcement. $\operatorname{Cov}_{b}, \operatorname{Cov}_{a}$, and $\operatorname{Cov}_{p}$ are serial covariance of daily closing bid, ask and transaction price. $S$ is the average proportional quoted bid-ask spread. Price is the cross-sectional average stock price for each event window. Volume is the average trading volume in the month. Turnover is the average cross-sectional turnover ratio for each period. Market value is the average market value of the firms in the sample. t-statistics are shown in parentheses. ${ }^{\mathrm{a}, \mathrm{b}}$ Indicate statistically significance at the 5 and 1 percent level, respectively.

Table 1 shows that the transaction volume (the number of outstanding shares times their transaction prices) and the turnover ratio (the number of shares traded divided by the outstanding shares) increase around earnings announcements, as predicted by Krinsky and Lee (1996). The mean differences, however, around the event window are not statistically significant. Admati and Pfleiderer (1988) argue that an increase in trading volume induces lower adverse selection, while Foster and Viswanathan (1990) suggest that an increase in volume induces greater information asymmetry. However, they agree that an observed increase in volume may have significant impact on the adverse-selection cost in the realized bid-ask spread. The univariate results in Table I suggest that changes in volume are not closely linked to information asymmetry and therefore not closely linked to the spread, reflecting that the relationship between the cost components is complex. Transactions on the Danish stock market suggest that the average proportional bid-ask spread increase between the event and post-event window and it is statistically significant at the 5 percent level, while the change between the pre-event and event windows does not show an increase that is statistically significant. Krinsky and Lee (1996) argue that earnings announcements have an impact on information asymmetry because of changes in the individual components in the bid-ask spread.

Table 1 shows that the serial covariance of the quoted bid and ask prices undergoes a significant increase from the pre-event window to the event and post-event windows. A possible interpretation of the wider quoted bid-ask spread around earnings announcements is that the market makers suspect an increased level of information asymmetry. Jaffe and Winkler (1976) argue that firm-specific information may lead to greater information asymmetry, i.e., differences in the trading behavior of informed versus uninformed market participants. A wider bid-ask spread offsets higher expected losses to the market makers for trading with informed investors.

The univariate results in Table I when comparing changes in volume and spread suggest conflicting evidence regarding the relevance of information asymmetry to the bid-ask spread. Thus, the next section investigates and presents multivariate results of the magnitude of the bid-ask spread and the behavior of the three individual cost components.

\subsection{Empirical Estimation}

Multivariate regressions are used to estimate the three cost components: adverse-selection, the inventory-holding, and the order-processing, regressing the observed serial covariance against the squared bid-ask spread. Following Krinsky and Lee (1996), the estimated parameters are obtained for each event window by averaging the estimates of the OLS coefficients of $\alpha_{l}$ and $\beta_{l}$. The proportional bid-ask spread is dependent on the observed serial covariance from the difference in transaction returns and the bid-bid and ask-ask returns, i.e., the quoted bid to realized bid. Returns are used instead of price differences to eliminate the autocovariance in time-varying expected returns (George et al., 1991). Regressions (6) and (7) are used to estimate the price continuation parameter $\partial$ and the probability for a price reversal $\pi$.

$$
\begin{aligned}
& \operatorname{Cov}_{p}=\alpha_{o}+\alpha_{1} \cdot S^{2}+u \\
& \operatorname{Cov}_{a, b}=\beta_{o}+\beta_{1} \cdot S^{2}+v
\end{aligned}
$$

$S$ denotes the quoted proportional spread as the difference between the ask and bid prices, divided by the average of the ask and the bid; $\operatorname{cov}_{p}$ is the serial covariance of the returns of the transaction closing prices; $\operatorname{cov}_{a, b}$ is the serial covariance of the returns of the bid and ask prices; $u, v$ are random errors. The intermediate values of $\partial$ and 
$\pi$ are found from two auxiliary equations that express the parameters used to estimate the magnitude of the bid-ask spread.

$$
\begin{gathered}
\alpha_{1}=\partial^{2} \cdot(1-2 \cdot \pi)-\pi^{2} \cdot(1-2 \cdot \partial) \\
\beta_{1}=\partial^{2} \cdot(1-2 \cdot \pi)
\end{gathered}
$$

Stoll (1989) presents three empirical assumptions for $\pi$ and $\partial$. First, the market is efficient in the sense that the expected price change in a security is independent of current and past information. Second, the quoted bid-ask spread, $S$, is constant over the analyzed period of one-month. It is possible to relax this assumption to allow for random variations in the bid-ask spread. Third, all transactions are carried out at the highest bid and or at the lowest ask price available in the market. Based on these assumptions the three cost components of the bid-ask spread are determined as:

$$
\begin{aligned}
& \text { Adverse-selection costs: }[1-2 \cdot(\pi-\partial)] \\
& \text { Inventory-holding costs: } 2 \cdot(\pi-0.5) \\
& \text { Order-processing costs: }(1-2 \cdot \partial)
\end{aligned}
$$

Stoll's (1989) method provides estimates of the cost in cents for each component of the spread per dollar of stock

\begin{tabular}{|c|c|c|c|c|}
\hline Panel A: Bid & Dependent Variable & $\beta_{0}$ & $\beta_{1}$ & $\mathrm{R}^{2}$ \\
\hline Pre-event & $\operatorname{Cov}_{b}$ & $\begin{array}{c}-0.000022 \\
(-1.13)\end{array}$ & $\begin{array}{c}-0.058436 \\
(-3.56)\end{array}$ & 0.0205 \\
\hline Event & $\operatorname{Cov}_{b}$ & $\begin{array}{c}-0.000069 \\
(-3.68)\end{array}$ & $\begin{array}{c}-0.038617 \\
(-2.06)\end{array}$ & 0.0071 \\
\hline Post-event & $\operatorname{Cov}_{b}$ & $\begin{array}{c}-0.000096 \\
(-3.50)\end{array}$ & $\begin{array}{c}-0.024896 \\
(-1.41)\end{array}$ & 0.0033 \\
\hline \multicolumn{5}{|l|}{ Panel B: Ask } \\
\hline Pre-event & $\operatorname{Cov}_{a}$ & $\begin{array}{c}-0.000020 \\
(-2.01)\end{array}$ & $\begin{array}{c}-0.031281 \\
(-3.77)\end{array}$ & 0.0229 \\
\hline Event & $\operatorname{Cov}_{a}$ & $\begin{array}{c}-0.000086 \\
(-3.35)\end{array}$ & $\begin{array}{c}-0.039381 \\
(-1.53)\end{array}$ & 0.0039 \\
\hline Post-event & $\operatorname{Cov}_{a}$ & $\begin{array}{c}-0.000076 \\
(-3.85)\end{array}$ & $\begin{array}{c}-0.080244 \\
(-6.36)\end{array}$ & 0.0635 \\
\hline \multicolumn{5}{|l|}{ Panel C: Price } \\
\hline Pre-event & $\operatorname{Cov}_{p}$ & $\begin{array}{c}0.000033 \\
(1.23)\end{array}$ & $\begin{array}{c}-0.116876 \\
(-5.27)\end{array}$ & 0.0439 \\
\hline Event & $\operatorname{Cov}_{p}$ & $\begin{array}{c}0.000012 \\
(0.56)\end{array}$ & $\begin{array}{c}-0.072412 \\
(-3.46)\end{array}$ & 0.0197 \\
\hline Post-event & $\operatorname{Cov}_{p}$ & $\begin{array}{c}0.000037 \\
(2.27)\end{array}$ & $\begin{array}{c}-0.128872 \\
(-12.26)\end{array}$ & 0.2012 \\
\hline
\end{tabular}
price, multiplying the proportional components of the percentage-spread to measure the costs per dollar of price. Table 2 shows the results of serial covariance against the squared proportional bid-ask spread for the pre-event, event, and post-event window.

Table 2. Regression results

Note. Regression of serial covariance against the squared proportional bid-ask spread for the pre-event, event, and post-event window. Cov $_{b}$, $\operatorname{Cov}_{a}$, and $\operatorname{Cov}_{p}$ are serial covariance of daily closing bid, ask and transaction price. $S$ is the average proportional bid-ask spread. The estimation parameters $\alpha_{l}$ and $\beta_{l}$ are from $\operatorname{cov}_{a, b}=\beta_{0}^{a, b}+\beta_{1}^{a, b} \cdot S^{2}+\varepsilon^{a, b}$ and $\operatorname{cov}_{p}=\alpha_{0}^{p}+\alpha_{1}^{p} \cdot S^{2}+\varepsilon^{p}$, respectively. Panel A is for bid prices, Panel B is for ask, and Panel C is for transaction prices. t-statistics are shown in parentheses. ${ }^{\mathrm{a}, \mathrm{b}}$ Statistically significance at the $1 \%$ and $5 \%$ levels, respectively.

Table 2 Panel A shows bid prices, Panel B shows ask prices, and Panel C shows transaction prices. Panel A and Panel B show that the estimated value of $\beta_{1}$, i.e., the average coefficient based on the serial covariance of the bid and the ask prices. The average $\beta_{l}$ coefficients are negative and statistically significant in four of the six estimations, showing support for the inventory-holding cost explanation (Stoll, 1989). Panel C shows that the average $\alpha_{1}$ coefficients are negative and statistically significant. Similar to the findings in Stoll (1989), this result confirms the expectation of the implied spread, i.e., $\operatorname{cov}_{p} \leq 0.0$. The overall values of $\alpha_{1}$ are $-0.117,-0.072$, and 
-0.129 in the pre-event, event, and post-event window, respectively. The cross-sectional variation of the serial covariance that is explained by the squared bid-ask spread are 4.39 percent, 1.97 percent, and 20.12 percent in the pre-event, event, and post-event window, respectively.

Under an assumption of market efficiency, the expected value for both $\alpha_{0}$ and $\beta_{0}$ is 0.0 . However, the estimated values are significant in six of the nine estimations. The estimation using transaction prices suggests that $\alpha_{0}$ is small and positive, while the estimations based on bid and ask prices, $\beta_{0}$ is small and negative. Stoll (1989) argues that positive intercepts reflects a form of market efficiency due to a delay in price adjustments. He further argues that the negative intercepts, $\beta_{0}$, reflect the differences in actual transaction sizes that exceed the transaction implied by the quoted bid-ask spread. The relationship between the quoted and realized spread is further examined using the following equations:

$$
\begin{aligned}
\operatorname{cov}_{p} & =\alpha_{0}+\alpha_{1} \cdot S^{2}+\alpha_{2} \cdot S^{2} \cdot X \\
\operatorname{cov}_{a, b} & =\beta_{0}+\beta_{1} \cdot S^{2}+\beta_{2} \cdot S^{2} \cdot X
\end{aligned}
$$

where $a_{1}=\alpha_{1}+\alpha_{2} \cdot X$ and $b_{1}=\beta_{1}+\beta_{2} \cdot X$. The serial covariance can be explained by the average stock price, the average daily volume divide by outstanding shares, the turnover ratio the average daily volume divided by outstanding shares, and the average market value. The turnover ratio is indicative of the degree of informational trading, and therefore reflects the adverse-selection costs. It is further expected that the transition from the pre-event to the event window around earnings announcements exhibits an increase in information asymmetry. Roll (1984) shows that the implied spread is related to firm size. Stoll (1989) argues that the quoted spread is related to the transaction volume, the stock price, the number of market makers, and the underlying risk of the security. He also argues that in the absence of information asymmetry, trading happens in proportions to the outstanding transaction amount. Affleck-Graves et al. (1994) argue that important elements of the bid-ask spreads are measured by the structure of trading and stock specific characteristics.

\begin{tabular}{|c|c|c|c|c|c|c|c|c|c|c|c|c|c|}
\hline \multirow{2}{*}{$\begin{array}{c}\text { Dependent } \\
\text { Variable } \\
\end{array}$} & \multirow[b]{2}{*}{$\mathrm{X}$} & \multirow[b]{2}{*}{$\alpha_{0}$} & \multicolumn{2}{|c|}{ Pre-Event window } & \multirow[b]{2}{*}{$\mathrm{R}^{2}$} & \multirow[b]{2}{*}{$\alpha_{0}$} & \multicolumn{2}{|c|}{ Event window } & \multirow[b]{2}{*}{$\mathrm{R}^{2}$} & \multirow[b]{2}{*}{$\alpha_{0}$} & \multicolumn{2}{|c|}{ Post-Event window } & \multirow[b]{2}{*}{$\mathrm{R}^{2}$} \\
\hline & & & $\alpha_{1}$ & $\alpha_{2}$ & & & $\alpha_{1}$ & $\alpha_{2}$ & & & $\alpha_{1}$ & $\alpha_{2}$ & \\
\hline \multirow[t]{8}{*}{$\operatorname{Cov}_{\text {price }}$} & Price & 0.000037 & -0.0001 & -0.1027 & 0.045 & 0.000004 & 0.0001 & -0.1050 & 0.031 & 0.000039 & 0.0000 & -0.1360 & 0.202 \\
\hline & & $(1.35)$ & $(-0.86)$ & $(-3.71)^{\mathrm{b}}$ & & $(0.18)$ & $(2.65)^{\mathrm{b}}$ & $(-4.32)^{\mathrm{b}}$ & & $(2.32)^{\mathrm{b}}$ & $(0.83)$ & $(-10.06)^{b}$ & \\
\hline & Volume & 0.000028 & 0.0015 & -0.1272 & 0.050 & -0.000026 & -0.0001 & 0.0317 & 0.007 & 0.000008 & 0.0011 & -0.0726 & 0.063 \\
\hline & & $(0.89)$ & $(0.87)$ & $(-5.16)^{b}$ & & $(-1.44)$ & $(-0.09)$ & $(1.83)^{\mathrm{a}}$ & & $(0.49)$ & $(1.08)$ & $(-5.60)^{\mathrm{b}}$ & \\
\hline & Turnover & 0.000026 & 0.7731 & -0.1303 & 0.052 & -0.000031 & 0.5976 & 0.0288 & 0.010 & 0.000010 & -0.0802 & -0.0664 & 0.061 \\
\hline & & $(0.82)$ & $(1.20)$ & $(-5.26)^{b}$ & & $(-1.74)$ & $(1.36)$ & $(1.67)$ & & $(0.57)$ & $(-0.17)$ & $(-5.47)^{\mathrm{b}}$ & \\
\hline & Market & 0.000024 & 0.0000 & -0.1311 & 0.052 & 0.000003 & 0.0000 & -0.0782 & 0.022 & 0.000053 & 0.0000 & -0.1206 & 0.246 \\
\hline & & $(0.88)$ & $(2.27)^{\mathrm{b}}$ & $(-5.69)^{\mathrm{b}}$ & & $(0.12)$ & $(1.13)$ & $(-3.61)^{\mathrm{b}}$ & & $(3.24)^{\mathrm{b}}$ & $(-5.15)^{\mathrm{b}}$ & $(-10.62)^{\mathrm{b}}$ & \\
\hline \multirow[t]{8}{*}{$\operatorname{Cov}_{\text {ask }}$} & Price & -0.000010 & -0.0001 & 0.0050 & 0.079 & -0.000081 & -0.0001 & -0.0178 & 0.007 & -0.000071 & 0.0000 & -0.1094 & 0.077 \\
\hline & & $(-0.96)$ & $(-6.06)^{b}$ & $(0.50)$ & & $(-3.10)^{b}$ & $(-1.42)$ & $(-0.60)$ & & $(-3.59)^{b}$ & $(2.91)^{\mathrm{b}}$ & $(-6.78)^{b}$ & \\
\hline & Volume & -0.000024 & 0.0003 & -0.0297 & 0.020 & -0.000097 & 0.0001 & -0.0319 & 0.002 & -0.000077 & 0.0038 & -0.1001 & 0.072 \\
\hline & & $(-1.99)^{\mathrm{a}}$ & $(0.53)$ & $(-3.19)^{b}$ & & $(-3.17)^{\mathrm{b}}$ & $(0.05)$ & $(-1.08)$ & & $(-3.69)^{\mathrm{b}}$ & $(2.97)^{\mathrm{b}}$ & $(-6.10)^{b}$ & \\
\hline & Turnover & -0.000024 & 0.2413 & -0.0311 & 0.021 & -0.000097 & 0.0136 & -0.0320 & 0.002 & -0.000076 & 0.3462 & -0.0828 & 0.056 \\
\hline & & $(-2.07)^{\mathrm{b}}$ & (0.99) & $(-3.32)^{b}$ & & $(-3.15)^{b}$ & $(0.02)$ & $(-1.09)$ & & $(-3.57)^{\mathrm{b}}$ & $(0.59)$ & $(-5.35)^{b}$ & \\
\hline & Market & -0.000019 & 0.0000 & -0.0292 & 0.024 & -0.000090 & 0.0000 & -0.0412 & 0.004 & -0.000068 & 0.0000 & -0.0950 & 0.081 \\
\hline & & $(-1.87)^{\mathrm{a}}$ & $(-0.87)$ & $(-3.37)^{b}$ & & $(-3.29)^{\mathrm{b}}$ & $(0.33)$ & $(-1.55)$ & & $(-3.42)^{\mathrm{b}}$ & $(-0.07)$ & $(-6.85)^{b}$ & \\
\hline \multirow{8}{*}{$\operatorname{Cov}_{\text {bid }}$} & Price & -0.000009 & -0.0002 & -0.0125 & 0.044 & -0.000061 & -0.0001 & -0.0038 & 0.024 & -0.000095 & 0.0000 & -0.0339 & 0.004 \\
\hline & & $(-0.44)$ & $(-3.81)^{\mathrm{b}}$ & $(-0.61)$ & & $(-3.24)^{\mathrm{b}}$ & $(-3.16)^{b}$ & $(-0.18)$ & & $(-3.41)^{\mathrm{b}}$ & $(0.65)$ & $(-1.50)$ & \\
\hline & Volume & -0.000028 & -0.0008 & -0.0580 & 0.022 & -0.000073 & -0.0012 & -0.0368 & 0.010 & -0.000065 & 0.0022 & -0.1225 & 0.051 \\
\hline & & $(-1.15)$ & $(-0.62)$ & $(-3.11)^{b}$ & & $(-3.38)^{\mathrm{b}}$ & $(-1.24)$ & $(-1.76)^{\mathrm{a}}$ & & $(-2.11)^{b}$ & (1.17) & $(-5.02)^{b}$ & \\
\hline & Turnover & -0.000029 & -0.0326 & -0.0599 & 0.021 & -0.000077 & -0.0148 & -0.0383 & 0.007 & -0.000056 & -0.7606 & -0.1065 & 0.050 \\
\hline & & $(-1.23)$ & $(-0.07)$ & $(-3.19)^{b}$ & & $(-3.51)^{\mathrm{b}}$ & $(-0.03)$ & $(-1.83)^{\mathrm{a}}$ & & $(-1.78)^{\mathrm{a}}$ & $(-0.88)$ & $(-4.67)^{\mathrm{b}}$ & \\
\hline & Market & -0.000025 & 0.0000 & -0.0627 & 0.022 & -0.000066 & 0.0000 & -0.0372 & 0.007 & -0.000112 & 0.00091 & -0.0647 & 0.058 \\
\hline & & $(-1.26)$ & $(0.95)$ & $(-3.66)^{b}$ & & $(-3.31)^{\mathrm{b}}$ & $(-0.35)$ & $(-1.92)^{\mathrm{a}}$ & & $(-4.12)^{b}$ & $(5.78)^{\mathrm{b}}$ & $(-3.40)^{\mathrm{b}}$ & \\
\hline
\end{tabular}

Table 3. Explanation of the bid-ask spread

Note. The sample includes earnings announcements from firms on the Copenhagen Stock Exchange between 1989 and 1996 . The pre-event window is from 45 days to 16 day before an earnings announcement. The event window is from 15 days before to 15 days after an announcement. The post-event is 16 to 45 days after earnings announcement. $\operatorname{Cov}_{b}, \operatorname{Cov}_{a}$, and $\operatorname{Cov}_{p}$ are serial covariance of daily closing bid, ask and transaction price. Price is the cross-sectional average stock price for each event window. Volume is the average trading volume in the month. Turnover is the average cross-sectional turnover ratio for each period. Market value is the average market value of the firms in the sample. t-statistics are shown in parentheses. ${ }^{\text {a, }}$ Statistically significance at the $1 \%$ and $5 \%$ levels, respectively. 
Table 3 presents a possible explanation of the economic magnitude of the bid-ask spread. It shows that the stock characteristics do not influence the estimation parameter, $\alpha_{1}$. Table 3 further shows that the cross-sectional difference is reflected in the bid-ask spread and not in the price parameters. The results suggest that the parameter $\alpha_{1}$ is not dependent on the stock characteristics of companies listed on CSE. The positive turnover ratio implies that the greater the turnover, the lesser the serial covariance. The stock price coefficient in $\operatorname{cov}_{\text {price }}$ is negative and statistically significant, while the coefficient in $\operatorname{cov}_{a, b}$ is only significant and negative in one of six regressions. The negative coefficient implies that higher stock prices lead to higher negative covariance.

\section{The Cost Components of the Bid-Ask Spread}

\subsection{Change in the Bid-Ask Spread and the Cost Components}

Panel A of Table 4 shows that the information asymmetry changes around earnings announcements made by companies on the Danish stock market. The adverse-selection costs increase from 55 percent to 72 percent of the quoted proportional bid-ask spread. Following earnings announcements in the post-event window, the adverse-selection costs decrease to 51 percent. The difference in the components between the event and pre-event windows and event and post-event windows is 16.4 percent and -20.6 percent. These findings are consistent with the findings in Kim and Verrecchia (1994) and Krinsky and Lee (1996). The results suggest that earnings announcements provide important pricing information by supplying the informed traders with information advantages over market makers. This also implies that the information disadvantage does not induce the market makers to increase the bid-ask spread.

Table 4 shows that the inventory-holding costs around earnings announcements are reduced to 18.9 percent from 26.7 percent in the pre-event window; however, the change is not statistically significant. (Note 6) The inventory-holding costs increase by 12.28 percent after the event window, which may be due to the increase in volume and turnover. Krinsky and Lee (1996) argue that higher volume induces the market makers to tighten the spread because of economics of scale while the increase in volatility induces wider spread, because of the risk of holding inventory. The order-processing cost declines from 17.9 percent in the pre-event window to 9.3 percent in the event window, the change is not statistically significant.

The quoted spread is the expected difference between a purchase price and a sale price, i.e., the spread is $2 \cdot(\pi-\partial) \cdot S$. This spread represents the market makers' expected profit, but changes to the realized spread from this expectation indicate a decrease in the market makers' realized profit. As shown in Table 4 Panel B, the magnitude of the change in cost components per dollar. The adverse-selection costs of an average stock price at 486.12 (DKK) during the post-event window (see Table 1) decreases by 57.75 (DKK), while the average realized bid-ask spread increases by 281.89 (DKK) per round trip transaction.

Table 4. Components in the bid-ask spread

\begin{tabular}{|c|c|c|c|c|c|c|}
\hline & \multicolumn{3}{|c|}{ Estimated Components } & \multicolumn{3}{|c|}{ Difference } \\
\hline & Pre-Event & Event & Post-Event & Event-Pre-Event & Post-Event & Post - Pre-Event \\
\hline \multicolumn{7}{|c|}{ Panel A: Proportion of Percentage Spread } \\
\hline Adverse selection cost & 0.5534 & 0.7170 & 0.5110 & $\begin{array}{l}0.1636 \\
(0.406)\end{array}$ & $\begin{array}{l}-0.2060 \\
(0.295)\end{array}$ & $\begin{array}{l}-0.0424 \\
(0.829)\end{array}$ \\
\hline Inventory holding cost & 0.2673 & 0.1897 & 0.3126 & $\begin{array}{l}-0.0775 \\
(0.301)\end{array}$ & $\begin{array}{l}0.1228 \\
(0.204)\end{array}$ & $\begin{array}{l}0.0453 \\
(0.380)\end{array}$ \\
\hline Order processing cost & 0.1793 & 0.0933 & 0.1765 & $\begin{array}{l}-0.0861 \\
(0.253)\end{array}$ & $\begin{array}{l}0.0832 \\
(0.259)\end{array}$ & $\begin{array}{l}-0.0029 \\
(0.491)\end{array}$ \\
\hline \multicolumn{7}{|c|}{ Panel B: Cost per Dollar of Price } \\
\hline Adverse selection cost & 0.9521 & 1.2311 & 1.1123 & $\begin{array}{l}0.2789 \\
(0.156)\end{array}$ & $\begin{array}{l}-0.1188 \\
(0.546)\end{array}$ & $\begin{array}{l}0.1602 \\
(0.416)\end{array}$ \\
\hline Inventory holding cost & 0.4598 & 0.3258 & 0.6804 & $\begin{array}{l}-0.1340 \\
(0.183)\end{array}$ & $\begin{array}{c}0.3547 \\
(0.008)^{\mathrm{c}}\end{array}$ & $\begin{array}{c}0.2206 \\
(0.068)^{\mathrm{a}}\end{array}$ \\
\hline Order processing cost & 0.3085 & 0.1601 & 0.3841 & $\begin{array}{l}-0.1484 \\
(0.125)\end{array}$ & $\begin{array}{c}0.2240 \\
(0.041)^{\mathrm{b}}\end{array}$ & $\begin{array}{l}0.0756 \\
(0.279)\end{array}$ \\
\hline
\end{tabular}

Note. Components of the bid-ask spread are estimate for the pre-event, event, and post event window. Stoll's (1989) methodology is used to estimate the spread. The pre-event window is from 45 days to 15 day before an earnings announcement. The event window is from 15 days before to 15 days after an announcement. The post-event is 15 to 45 days after earnings announcement. The sample includes a total of 690 announcements from firms on the Copenhagen Stock Exchange from 1989 to 1996. The cost per dollar of price estimates are obtained by multiplying proportional spread with the mean percentage spread, similar to the methodology by Affleck-Graves, Hedge, and Miller (1994). The p-values in parentheses are obtained using a bootstrap simulation involving 10,000 replications. ${ }^{\text {a,bc }}$ Statistically significance at the 10,5 , and 1 percent levels, respectively. 
Table 4 shows an increase in the adverse-selection cost, suggesting a change in information asymmetry. Krinsky and Lee (1996) find a similar increase in the adverse-selection cost that is statistically significant from 59.5 percent to 76.4 percent in the pre-event window to the event window. The inventory-holding and order-processing costs decrease by approximately 10 percent, suggesting that earnings announcements on the Danish stock market do not have a statistically significant impact on the realized spread, but it may increase information asymmetry. Similar to Krinsky and Lee (1996), Stoll (1989) finds an adverse-selection cost of 47 percent. In contrast, Venkatesh and Chiang (1986) find no increase in the information asymmetry unless the announcement of earnings is followed by another announcement in which there is a significant increase in the information asymmetry. Affleck-Graves et al. (1994) find that the adverse-selection cost is 50 percent on NYSE and 36 percent on NASDAQ, the inventory-holding cost is 47 percent for NYSE and 17 percent for NASDAQ, and the order-processing cost is 1 percent for NYSE and 47 percent NASDAQ. Thus, the economic magnitude of changes on the cost components on the Danish stock market around earnings announcements are similar to observed cost components on NYSE and NASDAQ.

\subsection{Positive and Negative Earnings Surprises}

Table 5 separates the announcements of earnings on the Danish stock market into positive and negative earnings surprises. Panel A in Table 5 shows that the change in the cost components of the realized spread among positive earnings surprises is statistically significant between the pre-event window and the event window. The inventory-holding cost increases from 15.9 percent to 25.5 percent, which implies that the market makers are holding more non-preferable inventory in order to maintain their liquidity service. To outweigh inventory-holding costs, the market makers reduce the order-processing costs. The realized spread, however, does not change in the case of positive earnings surprises, implying less information asymmetry among market participants. The cost per dollar of price for positive earnings surprises in Panel B shows an increase in the inventory-holding costs and a decrease in the order-processing costs, implying a decrease in the adverse-selection costs for an average stock price of DKK 538.25 around positive earnings surprises of DKK 3.45 ( $\varnothing \mathrm{re}$ ) during the event window. The average realized bid-ask spread increases by DKK 76.59 ( $\varnothing \mathrm{re}$ ) per round-trip transaction.

Table 5. Components of the bid-ask spread for positive and negative surprises

\begin{tabular}{|c|c|c|c|c|c|c|}
\hline \multicolumn{7}{|c|}{ Positive Earnings Surprises } \\
\hline & \multicolumn{3}{|c|}{ Estimated Components } & \multicolumn{3}{|c|}{ Difference } \\
\hline & Pre-Event & Event & Post-Event & Event-Pre-Event & Post-Event & Post-Pre-Event \\
\hline \multicolumn{7}{|c|}{ Panel A: Proportional of Percentage Spread } \\
\hline Adverse selection cost & 0.6392 & 0.5656 & 0.6325 & $\begin{array}{l}-0.0736 \\
(0.708)\end{array}$ & $\begin{array}{l}0.0669 \\
(0.734)\end{array}$ & $\begin{array}{c}-0.0067 \\
(0.973)\end{array}$ \\
\hline Inventory holding cost & 0.1591 & 0.4142 & 0.3069 & $\begin{array}{c}0.2551 \\
(0.043)^{\mathrm{b}}\end{array}$ & $\begin{array}{l}-0.1073 \\
(0.235)\end{array}$ & $\begin{array}{l}0.1478 \\
(0.159)\end{array}$ \\
\hline Order processing cost & 0.2017 & 0.0203 & 0.0606 & $\begin{array}{l}-0.1814 \\
(0.080)^{\mathrm{a}}\end{array}$ & $\begin{array}{l}0.0404 \\
(0.374)\end{array}$ & $\begin{array}{l}-0.1411 \\
(0.137)\end{array}$ \\
\hline \multicolumn{7}{|c|}{ Panel B: Cost per Dollar of Price } \\
\hline Adverse selection cost & 0.7229 & 0.7166 & 0.8507 & $\begin{array}{l}-0.0064 \\
(0.974)\end{array}$ & $\begin{array}{l}0.1341 \\
(0.496)\end{array}$ & $\begin{array}{l}0.1278 \\
(0.516)\end{array}$ \\
\hline Inventory holding cost & 0.1799 & 0.5247 & 0.4127 & $\begin{array}{l}0.3448 \\
(0.010)^{\mathrm{c}}\end{array}$ & $\begin{array}{l}-0.1120 \\
(0.225)\end{array}$ & $\begin{array}{c}0.2328 \\
(0.058)^{\mathrm{a}}\end{array}$ \\
\hline Order processing cost & 0.2282 & 0.0257 & 0.0816 & $\begin{array}{l}-0.2025 \\
(0.058)^{\mathrm{a}}\end{array}$ & $\begin{array}{l}0.0559 \\
(0.332)\end{array}$ & $\begin{array}{c}-0.1466 \\
(0.128) \\
\end{array}$ \\
\hline \multicolumn{7}{|c|}{ Negative Earnings Surprises } \\
\hline \multicolumn{7}{|c|}{ Panel C: Proportional of Percentage Spread } \\
\hline Adverse selection cost & 0.3046 & 0.6286 & 0.6994 & $\begin{array}{c}0.3239 \\
(0.099)^{\mathrm{a}}\end{array}$ & $\begin{array}{l}0.0709 \\
(0.719)\end{array}$ & $\begin{array}{c}0.3948 \\
(0.045)^{\mathrm{b}}\end{array}$ \\
\hline Inventory holding cost & 0.2849 & 0.0829 & 0.2613 & $\begin{array}{l}-0.2020 \\
(0.087)^{\mathrm{a}}\end{array}$ & $\begin{array}{l}0.1784 \\
(0.115)\end{array}$ & $\begin{array}{l}-0.0236 \\
(0.0437)\end{array}$ \\
\hline Order processing cost & 0.4105 & 0.2886 & 0.0393 & $\begin{array}{l}-0.1219 \\
(0.173)\end{array}$ & $\begin{array}{l}-0.2493 \\
(0.027)^{\mathrm{b}}\end{array}$ & $\begin{array}{l}-0.3712 \\
(0.002)^{\mathrm{c}}\end{array}$ \\
\hline
\end{tabular}




\begin{tabular}{lcccccc}
\hline \multicolumn{2}{l}{ Panel D: Cost per Dollar of Price } & \multicolumn{7}{l}{} \\
\hline Adverse selection cost & 0.4963 & 0.9963 & 1.0443 & 0.5000 & 0.0480 & 0.5480 \\
& & & & $(0.011)^{\mathrm{b}}$ & $(0.801)$ & $(0.005)^{\mathrm{c}}$ \\
Inventory holding cost & 0.4641 & \multirow{2}{*}{0.1313} & 0.3901 & -0.3328 & 0.2587 & -0.0740 \\
& & & & $(0.013)^{\mathrm{b}}$ & $(0.041)^{\mathrm{b}}$ & $(0.309)$ \\
Order processing cost & 0.6686 & \multirow{2}{*}{0.4574} & 0.0586 & -0.2113 & -0.3987 & -0.6100 \\
& & & & $(0.051)^{\mathrm{a}}$ & $(0.001)^{\mathrm{c}}$ & $(0.000)^{\mathrm{c}}$ \\
\hline
\end{tabular}

Note. Components of the bid-ask spread are estimate for the pre-event, event, and post event window. Stoll's (1989) methodology is used to estimate the spread. The pre-event window is from 45 days to 15 day before an earnings announcement. The event window is from 15 days before to 15 days after an announcement. The post-event is 15 to 45 days after earnings announcement. The sample includes a total of 690 announcements from firms on the Copenhagen Stock Exchange from 1989 to 1996. The cost per dollar of price estimates are obtained by multiplying proportional spread with the mean percentage spread, similar to the methodology by Affleck-Graves, Hedge, and Miller (1994). The p-values in parentheses are obtained using a bootstrap simulation involving 10,000 replications. ${ }^{\text {ab, }, c}$ Statistically significance at the 10,5 , and 1 percent levels, respectively.

Panel $\mathrm{C}$ in Table 5 shows an increase in the information asymmetry that is statistically significant between the pre-event window, the event window, and the post-event window for negative earnings surprises. The negative 20.2 percent decrease in inventory-holding costs implies that market makers hold less inventory in which information asymmetry exists. Between the event window and the post-event window, the inventory-holding cost is reversed, implying that the change in the realized bid-ask spread is temporary in the event window. The decrease from 69.5 percent to 37.2 percent in the realized spread (or gross profit) from pre-event window to event window suggests that it is costly for the market makers when trading with informed market participants.

Panel D shows the cost per dollar of price for negative earnings surprises decrease in the inventory-holding and order-processing costs. This change in transaction costs is statistically significant. The economic magnitude of a change in the adverse-selection costs around negative earnings surprises for an average stock price of DKK 452.46 increases by DKK 2.26 during the event window.

Overall, the results in Table 5 show an increasing and statistically significant adverse-selection cost around negative earnings surprises. The component represents 62.9 percent ( 30.5 percent) of the quoted bid-ask spread for the event (pre-event) window. A result that implies information asymmetry among market participants and more information uncertainty around negative earnings surprises than around positive earnings surprises. One possible explanation is that earnings information below expected creates increased uncertainty among market participants. The results support the hypothesis of an increase in the adverse-selection costs of the bid-ask spread. The results further support the hypothesis by Krinsky and Lee (1996) that the adverse-selection cost continues to be elevated following negative earnings surprises. Thus, the bid-ask spread increases around negative earnings announcement based on data from the small Danish stock market is caused by concerns about asymmetric information that is more pronounced than the reduction in inventory and order-processing costs caused by higher trading volume.

\section{Conclusion}

The changes in the realized bid-ask spread cost components around earnings announcements on the Danish stock market suggest that earnings surprises convey pricing information and significant informational asymmetry between market makers and informed traders. The cost component of the bid-ask spread on the Danish stock market is similar to that of large and more active capital markets. Around earnings announcements, adverse-selection costs and the trading volume increase, while the inventory-holding and order-processing costs decrease, resulting in no significant variation to the quoted bid-ask spread. This result indicates that earnings announcements are correlated with an increase in information asymmetry among market participants, with informed traders obtaining a greater informational advantage over market makers beyond the level of information asymmetry communicated by trading volume.

The realized bid-ask spread also does not change for positive surprises, but does significantly increase around negative surprises, suggesting greater the information asymmetry around unexpectedly negative earnings announcements. This suggests a differential in information asymmetry among market participants between positive and negative earnings surprises, with greater information asymmetry around the latter. The change in the realized bid-ask spread for negative surprises is temporary in the event window, implying a higher cost for market makers to trade with informed market participants around bad news. 


\section{Acknowledgments}

The views expressed in this article are solely those of the author, who is responsible for the content, and which does not necessarily represent the views of The Brattle Group.

\section{References}

Affleck-Graves, J., Hedge, S. P., \& Miller, R. E. (1994). Trading mechanisms and the components of the bid-ask spread. Journal of Finance, 49, 1471-1488. http://dx.doi.org/10.1111/j.1540-6261.1994.tb02462.x

Ajina, A., Danielle, S., \& Faten, L. (2015). Corporate Disclosures, Information Asymmetry And Stock-Market Liquidity In France. The Journal of Applied Business Research, 31, 1223-1238. http://dx.doi.org/10.19030/jabr.v31i4.9297

Cambell, J. Y., Andrew, W. L., \& MacKinlay, A. C. (1997). The Economics of Financial Markets. Princeton University Press.

Copeland, T., \& Galai, D. (1983). Information effects on the bid-ask spread. Journal of Finance, 38, 1457-1469. http://dx.doi.org/10.1111/j.1540-6261.1983.tb03834.x

Foster, F. G., \& Viswanathan, S. (1993). Variation in trading volume, return volatility, and trading costs: Evidence on recent price formation models. Journal of Finance, 48, 187-211. http://dx.doi.org/10.2307/2328886

George, T. H., Kaul, G., \& Nimalendran, M. (1991). Estimation of the bid-ask spread and its components: A new approach. Review of Financial Studies, 4, 623-656. http://dx.doi.org/10.1093/rfs/4.4.623

Glosten, L. R., \& Milgrom, P. R. (1985). Bid, ask, and transaction prices in specialist market with heterogeneously informed traders. Journal of Financial Economics, 14, 71-100. http://dx.doi.org/10.1016/0304-405X(85)90044-3

Gregoriou, A. (2013). Earnings announcements and the components of the bid-ask spread: Evidence from the London Stock Exchange. Journal of Economic Studies, 40, 112-126. http://dx.doi.org/10.1108/01443581311283646

Ho, T., \& Stoll, H. (1981). Optimal dealer pricing under transaction and return uncertainty. Journal of Financial Economics, 10, 47-74. http://dx.doi.org/10.1016/0304-405X(81)90020-9

Kim, O., \& Verrecchia, R. E. (1994). Market liquidity and volume around earnings announcements. Journal of Accounting and Economics, 17, 41-67. http://dx.doi.org/10.1016/0165-4101(94)90004-3

Krinsky, I., \& Lee, J. (1996). Earnings Announcements and the Components of the Bid-Ask Spread. Journal of Finance, 51, 1523-1534. http://dx.doi.org/10.1111/j.1540-6261.1996.tb04078.x

Singh, P., \& Pandey, A. (2013). Estimation of Bid-Ask Spread and its Components in Indian Stock Market based on Trade Prices. Working paper. http://dx.doi.org/10.2139/ssrn.2353207

Stoll, H. R. (1989). Inferring the components of the bid-ask spread: Theory and empirical tests. Journal of Finance, 44, 115-134. http://dx.doi.org/10.1111/j.1540-6261.1989.tb02407.x

Tatu, L., \& Tatu, D. (2008). Bid-Ask Spread and its Components Estimation for BSE stocks Using Models Based on Autocovariance. International Trade and Finance Association, Working paper.

Venkatesh, P. C., \& Chiang, R. (1986). Information asymmetry and the dealer's bid-ask spread: A case study of earnings and dividend announcements. Journal of Finance, 41, 1089-1102. http://dx.doi.org/10.1111/j.1540-6261.1986.tb02532.x

\section{Notes}

Note 1. See for example Roll (1984), Glosten (1987), Glosten and Harris (1988), Copeland and Galai (1988), Stoll (1989), George, Kaul and Nimalendran (1991), Affleck-Graves, Hedge, and Miller (1994), and Krinsky and Lee (1996).

Note 2. Krinsky and Lee (1996) compare announcement effects with the existence of asymmetric information about expected earnings. They find a correlation between significantly increased adverse-selection costs around earnings announcements and asymmetric information regarding such earnings.

Note 3. For studies of other markets, see for example Tatu and Tatu (2008, Bucharest Stock Exchange), Singh and Pandey (2013, Indian Stock Market), Ajina, Sougne, and Lakhal (2015, French Stock Exchange), and 
Gregoriou (2013, London Stock Exchange).

Note 4. Some of the first studies of the inventory-holding and order-processing costs include Demsetz (1968), Stoll (1978), Amihud and Mendelson (1980), and Ho and Stoll (1981, 1983). Studies of the adverse-selection costs include Copeland and Galai (1983), Glosten (1985), Glosten and Milgrom (1985), Easley and O’Hara (1987), and George, Kaul, and Nimalendran (1991).

Note 5. A formal proof is derived in Roll (1984) and Stoll (1989). Roll shows that when $\partial$ is 0 and $\pi$ is 0.5 then the $\operatorname{cov}_{\mathrm{p}}$ equals $-0.25 \cdot \mathrm{S}^{2}$.

Note 6. The difference between each event window is tested using a bootstrapping method proposed by Affleck-Graves et al. (1994).

\section{Copyrights}

Copyright for this article is retained by the author(s), with first publication rights granted to the journal.

This is an open-access article distributed under the terms and conditions of the Creative Commons Attribution license (http://creativecommons.org/licenses/by/4.0/). 